\title{
Human Hair as a Nutrient Source for Horticultural Crops
}

\author{
Valtcho D. Zheljazkov ${ }^{1,3}$, Juan L. Silva ${ }^{2}$, Mandar Patel $^{2}$, \\ Jelena Stojanovic ${ }^{2}$, Youkai $\mathrm{Lu}^{2}$, Taejo $\mathrm{Kim}^{2}$, and Thomas Horgan ${ }^{1}$
}

\begin{abstract}
AdDitional INDEX wORDs. lettuce, feverfew, yellow poppy, wormwood, Artemisia annua, Lactuca sativa, Glaucium flavum, Tanacetum parthenium, food quality, phenolics, hair waste
\end{abstract}

Summary. Two pot experiments were conducted to evaluate noncomposted hair byproduct as a nutrient source for container-grown crops. Lettuce (Lactuca sativa 'Green Leaves') and wormwood (Avtemisia annua 'Artemis') were grown in a commercial growth substrate amended with $0 \%, 2.5 \%, 5 \%$, or $10 \%$ by weight hair waste or controlled-release fertilizer (CRF) or were watered with a complete water-soluble fertilizer (WSF). After harvest, yellow poppy (Glaucium flavum) was grown in the pots and substrate that previously grew wormwood, and feverfew (Tanacetum parthenium) was grown in the pots and substrate previously containing lettuce. The $\mathbf{5 \%}$ hair treatment and the commercial fertilizer rates were calculated to provide the same amount of nitrogen $(\mathrm{N})$ during production of lettuce and wormwood based on $50 \% \mathrm{~N}$ availability from hair. Yields in treatments containing hair or CRF or watered with WSF were higher than in the untreated control. The highest lettuce and wormwood yields occurred with CRF followed by WSF and 5\% and 10\% hair treatments. However, yield of yellow poppy was higher in the hair treatments than yields in inorganic fertilizer treatments or in the untreated control. Feverfew yields did not differ among fertility treatments, but yields in fertility treatments were higher than those of control. Lettuce leaf moisture content was lower, but soluble solids were higher in plants in the hair waste treatments than in the WSF or CRF treatments. Total phenolics in lettuce did not differ among treatments. Total aerobic and coliforms plate counts were similar for all samples, averaging 6.0 and $1.2 \log \mathrm{cfu} / \mathrm{g}$, respectively. Results from this study suggest that noncomposted hair waste could be used as a nutrient source for container-grown plants. Hair waste should not be used as a single nutrient source for fast-growing plants because of the time needed for degradation of the hair before release of plant nutrients.

\section{A} number of waste materials and byproducts (such as animal manure, municipal solid waste composts, and sewage sludge) are used currently in agricultural crop production. Human hair waste generated by barbershops typically would be disposed of at waste sites,

This is a contribution of the Mississippi Agricultural and Forestry Experiments Station Journal article No 11266. This research was funded by USDA-ARS Specific Coop. Agreement 58-6402-4-026 with CRIS MIS-223010. The specific project was "Field Establishment of Medicinal Herbs and Potential for Commercial Production" awarded to Dr. Jeliazkov (Zheljazkov) and by MIS project awarded to Dr. J.L. Silva.

We thank Dr. Crofton Sloan, Dr. Frank Matta, and Dr. Normie Buehring of Mississippi State University and the anonymous reviewers of the journal for critically reading the manuscript and suggesting many improvements.

${ }^{1}$ Mississippi State University, North Mississippi Research and Extension Center, 5421 Highway 145 South, Verona, MS 38879

${ }^{2}$ Mississippi State University, Department of Food Science, Nutrition, and Health Promotion, Box 9805 Mississippi State, MS 39762

${ }^{3}$ Corresponding author. E-mail: vj40@pss.msstate. edu. couple of years (SmartGrow, FL City, FL).

The hypothesis of this study was that commercially available noncomposted hair waste cubes would support plant growth and the development of two consecutive crops (double cropping) and could be used as a sole nutrient source. The objective was to compare the productivity of four crops grown in commercial growth medium in pots with the following treatments: untreated control, noncomposted hair cubes at $2.5 \%, 5 \%$, and $10 \%$ by weight, a controlled-release fertilizer (CRF), and water-soluble fertilizer (WSF). As model plants, we used four container-grown crops: lettuce, wormwood, yellow poppy, and feverfew.

\section{Materials and methods}

Plant growth conditions. In Mar. 2007, two to three lettuce or wormword seeds were planted in each cell of 48 -cell $(6 \times 3.5 \mathrm{~cm}, 5 \mathrm{~cm}$ deep $)$ plastic trays filled with a commercial growth substrate (Metromix 300; Sun Gro Horticulture, Bellevue, WA). After emergence, seedlings were thinned to one plant per cell and grown in a greenhouse under natural daylight with day temperatures of $22^{\circ} \mathrm{C}$ to $25^{\circ} \mathrm{C}$ and a night temperature of $18{ }^{\circ} \mathrm{C}$. The experiment was initiated in Mar. 2007 and continued through Sept. 2007, when the second crops were harvested. Twenty days after emergence, lettuce seedlings were transplanted to 6inch-diameter pots containing $600 \mathrm{~g}$ of the same growth substrate used for transplant production, and wormwood was transplanted to 11 -inchdiameter pots containing $2800 \mathrm{~g}$ of growth substrate. Two different size pots were used to correspond to wormwood and lettuce plant sizes.

The experimental design was a randomized complete block design available to crop producers in the last

\begin{tabular}{llll}
\hline $\begin{array}{l}\text { Units } \\
\begin{array}{l}\text { To convert U.S. to SI, } \\
\text { multiply by }\end{array}\end{array}$ & U.S unit & SI unit & $\begin{array}{l}\text { To convert SI to U.S., } \\
\text { multiply by }\end{array}$ \\
\hline 29,574 & $\mathrm{fl} \mathrm{oz}$ & $\mu \mathrm{L}$ & $3.3814 \times 10^{-5}$ \\
29.5735 & $\mathrm{fl} \mathrm{oz}$ & $\mathrm{mL}$ & 0.0338 \\
2.54 & $\mathrm{Inch}(\mathrm{es})$ & $\mathrm{cm}$ & 0.3937 \\
25.4 & $\mathrm{Inch}(\mathrm{es})$ & $\mathrm{mm}$ & 0.0394 \\
1 & $\mathrm{mmho} / \mathrm{cm}$ & $\mathrm{dS} \cdot \mathrm{m}^{-1}$ & 1 \\
28.3495 & $\mathrm{oz}$ & $\mathrm{g}$ & 0.0353 \\
0.1 & $\mathrm{ppm}$ & $\mathrm{mg} / 100 \mathrm{~g}$ & 10 \\
1 & $\mathrm{ppm}$ & $\mathrm{mg} \cdot \mathrm{kg}^{-1}$ & 1 \\
$\left({ }^{\circ} \mathrm{F}-32\right) \div 1.8$ & ${ }^{\circ} \mathrm{F}$ & ${ }^{\circ} \mathrm{C}$ & $\left(1.8 \times{ }^{\circ} \mathrm{C}\right)+32$
\end{tabular}


with four replicates. Factors were crop (at two levels) and fertility (at six levels). Lettuce and wormwood were treated as one experiment, and second crops yellow poppy and feverfew were treated as a second experiment. Experimental treatments were as follows: hair waste cubes (Fig. 1; donated by SmartGrow) were incorporated and thoroughly mixed into the growth medium at $0 \%, 2.5 \%, 5 \%$, or $10 \%$ by weight $(0,70,140$, or 280 g, respectively) to provide $0,11.6$, 23.1 , or $46.2 \mathrm{~g} /$ pot total $\mathrm{N}$, respectively. The hair waste cubes contained $16.5 \% \mathrm{~N}, 0.01 \%$ phosphorus $(\mathrm{P})$, $0.01 \%$ potassium $(\mathrm{K}), 0.27 \%$ calcium (Ca), $0.05 \%$ magnesium $(\mathrm{Mg})$, and $0.23 \%$ sulfur $(S)$, as analyzed by the Mississippi State University Soil Testing Laboratory (Mississippi State, MS) using the method of Jones and Steyn (1973) and averaged from three replicates. Commercial fertilizer treatments included a topdress of CRF (Osmocote Plus 15N-9P-12K; Scotts-Sierra Horticultural Products, Marysville, $\mathrm{OH}$ ) or fertilization with $100 \mathrm{mg} \cdot \mathrm{kg}^{-1}$ of $\mathrm{N}$ with $1100 \mathrm{~mL}$ of WSF (greenhouse-grade $20 \mathrm{~N}-8.8 \mathrm{P}-$ $16.6 \mathrm{~K}$ general purpose fertilizer; Scotts-Sierra Horticultural Products) every $7 \mathrm{~d}$. The $5 \%$ hair treatment and the commercial fertilizer rates were applied to provide the same amount of $\mathrm{N}$ during the production cycle based on $50 \% \mathrm{~N}$ availability from the

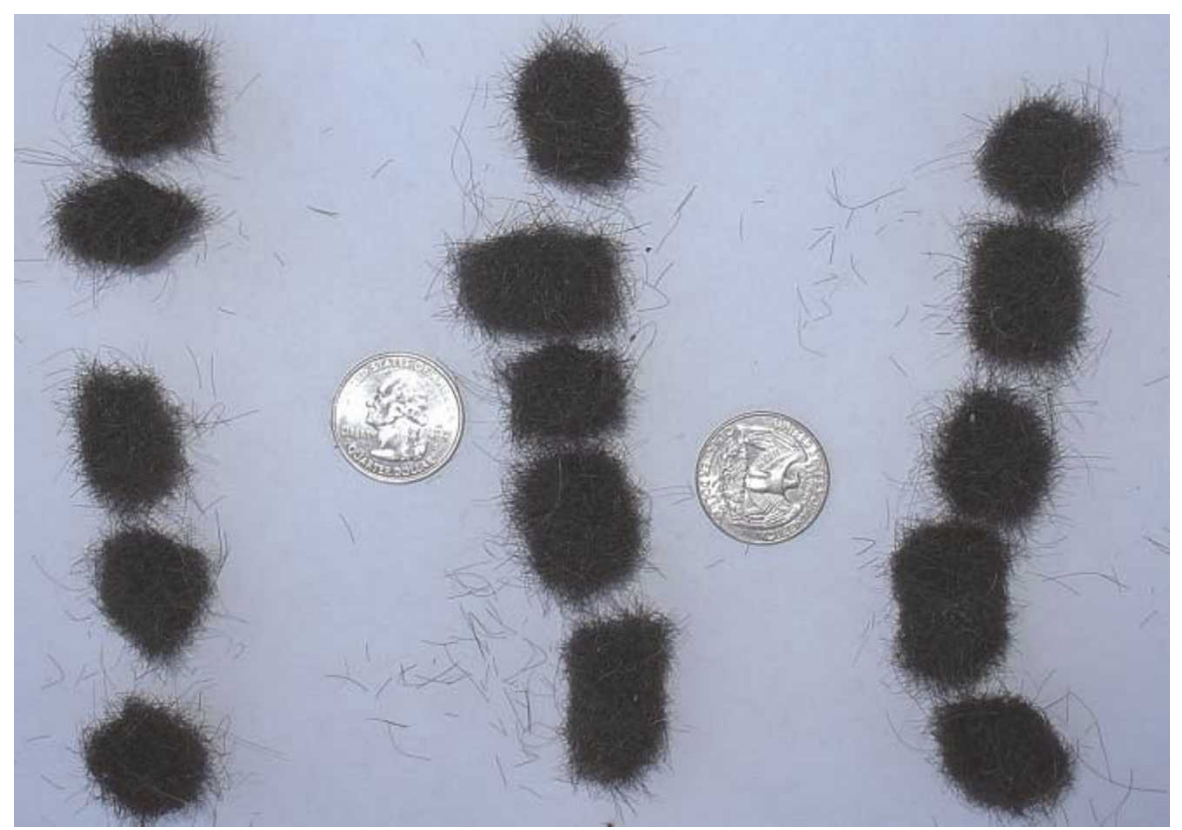

Fig. 1. Hair waste cubes used in this study. Coins are U.S. quarters $(\$ 0.25)$ with a diameter of $24.26 \mathrm{~mm}(1 \mathrm{~mm}=0.0394$ inch $)$.

hair waste as determined from previous research (Zheljazkov, 2005; Zheljazkov et al., 2008). CRF provided $2.5 \mathrm{~g} \mathrm{~N}, 1.5 \mathrm{~g} \mathrm{P}$, and $1.99 \mathrm{~g} \mathrm{~K}$ to each 6-inch-diameter pot, and $11.5 \mathrm{~g} \mathrm{~N}, 6.9 \mathrm{~g} \mathrm{P}$, and $9.3 \mathrm{~g} \mathrm{~K}$ to each 11 -inch-diameter pot. WSF provided $2.5 \mathrm{~g} \mathrm{~N}, 1.08 \mathrm{~g} \mathrm{P}$, and $2.06 \mathrm{~g} \mathrm{~K}$ to each 6-inch-diameter pot, and $11.5 \mathrm{~g} \mathrm{~N}, 5.06 \mathrm{~g} \mathrm{P}$, and $9.6 \mathrm{~g} \mathrm{~K}$ to each 11 -inch-diameter pot.

Plants were grown in a greenhouse with an average day/night temperature of $28 / 20{ }^{\circ} \mathrm{C}$ without supplemental lighting for $50 \mathrm{~d}$. Plants were watered daily as needed, by hand, making sure no leaching occurred. Lettuce and wormwood were harvested at commercial (marketable) maturity stage (six to eight fully developed leaves, about 12 inches tall). Plants were cut about $\mathrm{lcm}$ above the substrate, and height and fresh weight were recorded. About half of the lettuce samples were held at $4 \pm 1{ }^{\circ} \mathrm{C}$ until analyzed (less than $4 \mathrm{~d}$ ) or frozen (for phenolics). The wormwood samples and remaining half of the lettuce samples were dried in a drying oven at $68{ }^{\circ} \mathrm{C}$ for $72 \mathrm{~h}$ and weighed.

One week after the lettuce and wormwood were harvested, feverfew was planted into 6-inch-diameter pots and yellow poppy was transplanted into 11 -inch-diameter pots containing the growth substrate from

Hartecthology $\cdot$ October-December 2008 18(4) the previous crop. CRF and WSF were applied as described for the previous crops. No additional hair waste cubes were applied to the hair treatments. The feverfew and yellow poppy were grown for 20 weeks and were harvested in the same way as the previous crops.

Growth medium samples were taken after the harvest of the second crop, dried at room temperature, and extracted for phyto-available nutrients using the Lancaster soil test method (Cox, 2001). Determination of specific conductance (total soluble salts) was done using a conductivity meter (model 32; YSI, Yellow Springs, OH) (Willard et al., 1968). Nitrate-N was determined using a nitrate electrode (Francis and Malone, 1975).

Chemical and physical analysis of lettuce was conducted in three replicates from each treatment. Each replicate was an average of three readings. Water content of lettuce was determined by drying at $65{ }^{\circ} \mathrm{C}$ for $24 \mathrm{~h}$ [Association of Official Agricultural Chemists (AOAC) method 930.04 (AOAC, 1997)]. The soluble solids concentration (SSC; in percentage) in lettuce was evaluated using a refractometer (Bauch \& Lomb, Rochester, NY). The temperature was maintained at $21{ }^{\circ} \mathrm{C}$ with water circulating through the refractometer. The refractometer was calibrated using distilled water before each reading. After calibration, 1 drop of filtered lettuce juice was placed on a glass prism of the refractometer. The results were recorded and expressed as percentage of SSC (Stojanovic and Silva, 2007).

Total PHenolics. Lettuce samples from each treatment and replication were ground by mortar and pestle. A 5-g portion was homogenized with $15 \mathrm{~mL}$ of high-performance liquid chromatography-grade methanol (Fisher Scientific, Fair Lawn, NJ) in a homogenizer. The homogenizer was washed with $5 \mathrm{~mL}$ of methanol, which was combined with the first homogenate. Samples were centrifuged at $10,000 \mathscr{g}_{\mathrm{n}}$ for $15 \mathrm{~min}$ at $15^{\circ} \mathrm{C}$. The volume of the supernatant was recorded, and the pellet was discarded. Total phenolics in lettuce extract were determined with the Folin-Ciocalteu reagent by the method of Singleton and Rossi with gallic acid as the standard (Singleton 
and Rossi, 1965). Twenty microliters of sample was mixed directly in the cuvette with $1.58 \mathrm{~mL}$ of water and $100 \mu \mathrm{L}$ of Folin-Ciocalteu reagent (Fisher Scientific). The cuvette was incubated between 1 and 8 minutes, and $300 \mu \mathrm{L}$ of $20 \%$ sodium carbonate was added. Samples were incubated at room temperature for $2 \mathrm{~h}$, and absorbance was recorded at $765 \mathrm{~nm}$.

Color. The color of lettuce leaves was evaluated using a spectrocolorimeter (Labscan Model 6000 $0 /{ }^{\circ} 45$; Hunter Associates Laboratory, Fairfax, VA). The instrument was calibrated with two standard tiles (black and white) using a quartzhalogen lamp. Each lettuce sample was placed on a $10-\mathrm{mm}$-diameter port. Three readings were taken on two sides of each sample. The reflectance values of ' $L$ ' (brightness), ' $a$ ' (redness+/greenness-), 'b' (yellowness+/blueness-) were measured. Hue angle value $\left(\tan ^{-1} \mathrm{~b} / \mathrm{a}\right)$ and chroma or saturation index $\left[\mathrm{SI}=\left(\mathrm{a}^{2}+\mathrm{b}^{2}\right)^{1 / 2}\right]$ were calculated according to Silva et al. (2005).

Microbiological anAlysis. A sample of $25 \mathrm{~g}$ of lettuce was placed in a stomacher bag (whirl-pak ${ }^{\mathrm{TM}}$; Nasco, Fort Atkinson, WI) to which $225 \mathrm{~mL}$ of $0.1 \%$ sterile peptone water was added and the contents were massaged in a stomacher (Sweard Medical Limited, London) for $30 \mathrm{~s}$ (Allende et al., 2004; Kim et al., 2000). This was done to remove cells from the lettuce and place them into the solution. Total aerobic plate counts (APC) were determined by the spread plate method by using $0.1 \mathrm{~mL}$ of sampling dilution (American Public Health Association, 1992). Plate Count Agar (Difco; Becton, Dickinson \& Co., Lawrence, KS) was used as the growth medium. The APC plates were duplicated from each dilution and were incubated in an incubator (Precision Scientific, Champaign, IL) at $37^{\circ} \mathrm{C}$ for $48 \mathrm{~h}$. The colonies were counted, and the microbial counts were reported as $\log$ colony-forming units (cfu) per gram of lettuce. Total coliform counts were determined from the same dilution using violet red bile agar (Difco) and incubating at $37^{\circ} \mathrm{C}$ for up to $48 \mathrm{~h}$. Coliform counts were expressed as $\log$ cfu per gram.

Data analyses were performed using analysis of variance in Quattro Pro 10 (Corel Corp., Ottawa,
Canada). Means, whenever different, were separated by using Fisher's protected least significant difference (LSD) test. (SAS version 9.1 for Windows; SAS Institute, Cary, NC).

\section{Results}

The addition of hair waste cubes to the growth medium at $5 \%$ or $10 \%$ by weight increased lettuce and wormwood yields relative to the untreated control (Table 1). However, yields in the $5 \%$ or $10 \%$ hair waste treatments were lower than yields in the inorganic fertilizer treatments. The highest yields of lettuce and wormwood were obtained in the CRF treatments, followed by the WSF treatment. The yield response of the second crops yellow poppy and feverfew to the treatments was different from the first crops. Overall, the yellow poppy yields were greater in the hair treatments, lower in the commercial fertilizer treatments (CRF or WSF), and the lowest in the untreated control (the $0 \%$ hair treatment; Table 1). The highest yields were obtained in the $5 \%$ and $10 \%$ hair treatments, and yields in the CRF exceeded those in the WSF treatment. Feverfew yields in the fertility treatments were not different, but all were higher than in the untreated control (Table 1).

All hair-treated lettuce and the untreated control samples had lower $(P \leq 0.05)$ moisture and higher $(P \leq$ $0.05)$ SSC than the CRF or WSF samples. The SSC of the CRF samples was higher than that of the untreated control or hair-treated samples,

whereas the SSC value of WSF samples was not different from all others (Table 2). Total phenolics, color saturation or chroma, and 'b' color values did not differ $(P>0.05)$ among samples. Other color values varied among samples, with no clear differences between hair-fertilized samples and other treatments. Aerobic plate counts were about $6 \log \mathrm{cfu} / \mathrm{g}$, whereas total coliforms ranged 1.0 and $1.9 \log \mathrm{cfu} / \mathrm{g}$, with no clear differences due to hair fertilization (Table 2).

In general, the addition of hair waste to growth medium resulted in lower $\mathrm{pH}$ than the untreated control as measured after the harvest of the second crop (Table 3). Residual nitrate- $\mathrm{N}$ concentrations were higher in the $2.5 \%$ and $5 \%$ hair treatments and CRF treatments than in the WSF or control treatments. There was a significant amount of residual $\mathrm{P}$ in the inorganic treatments (CRF or WSF) relative to the other treatments. Residual K concentrations were greatest in the inorganic fertilizer treatments, lower in the hair treatments, and lowest in the control. Residual zinc concentrations were higher in the $10 \%$ hair and the CRF treatments relative to the other treatments. Residual sodium was higher in the CRF, lower in the WSF, $10 \%$, and $5 \%$ hair treatments, and lowest in the control. Overall, hair treatments resulted in increased total soluble solids (TSS) than in the other treatments. Because TSS concentrations in the hair treatments were below or at $0.3 \mathrm{mmho} / \mathrm{cm}$ [below 2 is

Table 1. Yields of lettuce, wormwood, feverfew, and yellow poppy grown in pots with different treatments of hair waste and fertilizers.

\begin{tabular}{|c|c|c|c|c|}
\hline \multirow[b]{3}{*}{ Treatment $^{\mathrm{z}}$} & \multicolumn{2}{|c|}{ First crop $^{y}$} & \multicolumn{2}{|c|}{ Second crop } \\
\hline & Lettuce & Wormwood & Yellow poppy & Feverfew \\
\hline & - & (g dry & age/pot $)^{\mathrm{x}}$ & \\
\hline Control ( $0 \%$ hair) & $108.7 \mathrm{e}^{\mathrm{w}}$ & $85.3 \mathrm{e}$ & $5.2 \mathrm{e}$ & $9.4 \mathrm{~b}$ \\
\hline $2.5 \%$ hair & $11.2 \mathrm{de}$ & $68.3 \mathrm{e}$ & $182.3 \mathrm{~b}$ & 60.6 \\
\hline $5 \%$ hair & $121.2 \mathrm{~cd}$ & $109.6 \mathrm{~d}$ & $306.1 \mathrm{a}$ & $52.4 \mathrm{a}$ \\
\hline $10 \%$ hair & $132.9 \mathrm{c}$ & $163.1 \mathrm{c}$ & $344.1 \mathrm{a}$ & $55.2 \mathrm{a}$ \\
\hline CRF & $486.7 \mathrm{a}$ & $418.6 \mathrm{a}$ & $113.0 \mathrm{c}$ & $80.2 \mathrm{a}$ \\
\hline WSF & $326.4 \mathrm{~b}$ & $243.3 \mathrm{~b}$ & $44.2 \mathrm{~d}$ & $48.9 \mathrm{a}$ \\
\hline
\end{tabular}

${ }^{\mathrm{z}}$ Hair treatments were added once to the growth medium, at planting of the first crop. The $2.5 \%, 5 \%$, and $10 \%$ hair represent addition of hair to the growth medium by weight, whereas the control does not have hair addition. Controlled-release fertilizer (CRF) was surface applied at planting of the first crop and again with the planting of the second crop, whereas the water-soluble fertilizer (WSF) fertilizer was added on weekly basis.

y First, lettuce and wormwood were grown in the treated pots. After harvest, yellow poppy was grown after wormwood and feverfew after lettuce.

${ }^{\mathrm{x}} \mathrm{lg}=0.0353 \mathrm{oz}$

"Means with the same letter within a column are not significantly different by Fisher's protected least significant difference test at $P \leq 0.05$ 
Table 2. Chemical analyses, leaf surface color, and microbial counts of lettuce grown at different fertility regimes.

\begin{tabular}{|c|c|c|c|c|c|c|c|c|c|c|}
\hline \multirow[b]{2}{*}{ Treatments $^{\mathrm{z}}$} & Water & $\mathrm{SSC}^{\mathrm{y}}$ & \multirow{2}{*}{$\begin{array}{l}\text { Phenolics } \\
(\mathrm{mg} / 100 \mathrm{~g})^{\mathrm{x}}\end{array}$} & \multirow[b]{2}{*}{$\mathrm{L}^{\mathrm{w}}$} & \multirow[b]{2}{*}{$a^{v}$} & \multirow[b]{2}{*}{$\mathbf{b}^{\mathbf{u}}$} & \multirow[b]{2}{*}{$\mathrm{Hue}^{\mathrm{t}}$} & \multirow[b]{2}{*}{ Chroma $^{\text {s }}$} & \multirow{2}{*}{\multicolumn{2}{|c|}{$\frac{\mathrm{APC}^{\mathrm{r}} \quad \mathrm{TCC}^{\mathrm{r}}}{---(\mathrm{cfu} / \mathrm{g})---}$}} \\
\hline & - & $\overline{c-\cdots-\cdots}$ & & & & & & & & \\
\hline \multicolumn{11}{|l|}{ Control } \\
\hline $2.5 \%$ hair & $90.6 \mathrm{~b}$ & $5.8 \mathrm{a}$ & 31.5 & $51.4 \mathrm{~b}$ & $-13.5 \mathrm{ab}$ & 21.0 & $123 \mathrm{a}$ & 25.0 & $6.0 \mathrm{ab}$ & $1.2 \mathrm{ab}$ \\
\hline $5 \%$ hair & $91.4 \mathrm{~b}$ & $5.2 \mathrm{a}$ & 38.7 & $56.9 \mathrm{ab}$ & $-13.2 \mathrm{ab}$ & 22.1 & $120 \mathrm{ab}$ & 25.8 & $6.0 \mathrm{a}$ & $1.0 \mathrm{~b}$ \\
\hline $10 \%$ hair & $90.0 \mathrm{~b}$ & $6.1 \mathrm{a}$ & 49.9 & $52.3 \mathrm{~b}$ & $-15.5 \mathrm{~b}$ & 23.7 & $123 \mathrm{a}$ & 28.3 & $5.6 \mathrm{~b}$ & $1.0 \mathrm{~b}$ \\
\hline
\end{tabular}

${ }^{2}$ Hair and controlled-release fertilizer (CRF) were added once to the growth medium, and the water-soluble fertilizer (WSF) was added on weekly basis. The $2.5 \%, 5 \%$, and $10 \%$ hair represent addition of hair to the growth medium by weight, whereas the control does not have hair addition.

${ }^{y} \mathrm{SSC}=$ soluble solids content.

${ }^{\mathrm{x}} 1 \mathrm{mg} / \mathrm{l} 00 \mathrm{~g}=10 \mathrm{ppm}$.

${ }^{\mathrm{w}} \mathrm{L}=$ brightness value; the higher, the brighter.

$\mathrm{v}$ a $=$ redness value.

${ }^{\mathrm{u}} \mathrm{b}=$ yellowness value.

${ }^{t}$ Hue $=\operatorname{atan}(\mathrm{b} / \mathrm{a})$.

${ }^{\mathrm{s}}$ Chroma $=$ saturation index $=\left(\mathrm{a}^{2}+\mathrm{b}^{2}\right)^{1 / 2}$

${ }^{\mathrm{r}} \mathrm{APC}=$ aerobic or total plate counts, TCC $=$ total coliform counts $(\mathrm{l} \mathrm{cfu} / \mathrm{g}=28.3495 \mathrm{cfu} / \mathrm{oz})$.

${ }^{\mathrm{q}}$ Means with the same letter within a column are not significantly different by Fisher's protected least significant difference test at $P \leq 0.05$

Table 3. Growth medium $\mathrm{pH}$, residual nitrate $=\mathrm{N}$, extractable nutrients, and conductivity at harvest of wormwood and feverfew ${ }^{\mathrm{z}}$ as a function of addition of fertilizer of hair waste.

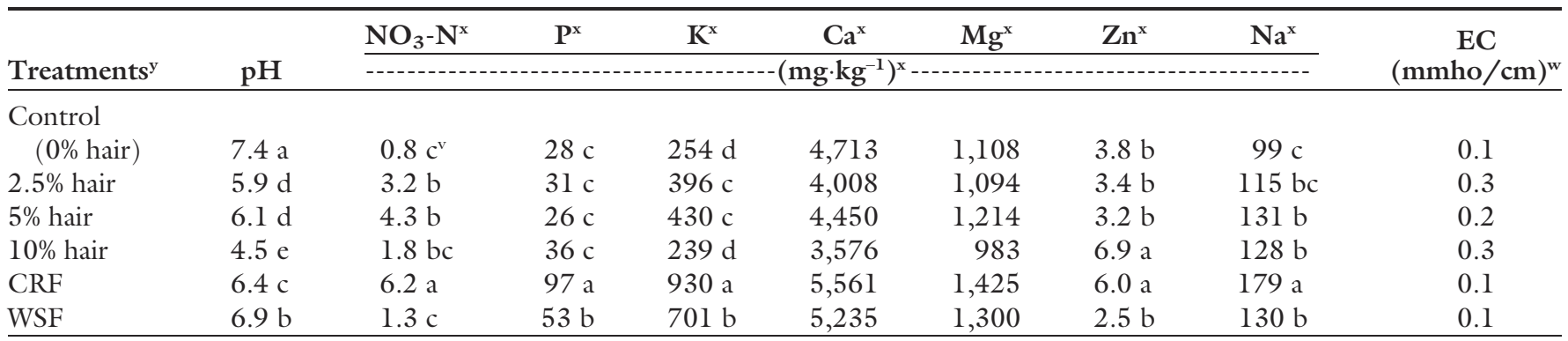

${ }^{z}$ First, lettuce and wormwood were grown in the treated pots. After harvest, yellow poppy was grown after wormwood and feverfew after lettuce.

y Hair and controlled-release fertilizer (CRF) were added once to the growth medium, and water-soluble fertilizer (WSF) was added on weekly basis. The $2.5 \%, 5 \%$, and $10 \%$ hair represent addition of hair to the growth medium by weight, whereas the control does not have hair addition.

${ }^{\mathrm{x}} \mathrm{NO}_{3} \cdot \mathrm{N}=$ nitrate nitrogen, $\mathrm{P}=$ phosphorus, $\mathrm{K}=$ potassium, $\mathrm{Ca}=$ calcium, $\mathrm{Mg}=$ magnesium, $\mathrm{Zn}=\mathrm{zinc}, \mathrm{Na}=\operatorname{sodium}\left(\mathrm{l} \mathrm{mg} \cdot \mathrm{kg}^{-1}=1 \mathrm{ppm}\right)$.

${ }^{\mathrm{w}} \mathrm{EC}=\mathrm{EC}\left(1 \mathrm{mmho} / \mathrm{cm}=1 \mathrm{dS} \cdot \mathrm{m}^{-1}\right)$.

${ }^{v}$ Means with the same letter within a column are not significantly different by Fisher's protected least significant difference test at $P \leq 0.05$.

considered low (Bernstein, 1975)], no further spot-plate screen was conducted to identify specific salts in the extract.

\section{Discussion}

Results from this study suggest that once the degradation and mineralization of hair waste starts, it can provide sufficient nutrients to container-grown plants and ensure similar yields to those obtained with the commonly used fertilizers in horticulture. However, it takes time for the hair to start degrading and releasing nutrients, as is reflected in lower yields in the hair treatments relative to the inorganic fertilizers for the first crops, lettuce and wormwood. Hence, this and previous research (Zheljazkov, 2005) suggests that unless sufficient time is allowed for nutrient mineralization, hair waste may not be suitable for fast-growing vegetables such as lettuce unless mixed with compost or other sources of easily available nutrients. Human hair is a keratinaceous substance that is very resistant to degradation by proteolytic enzymes such as trypsin and pepsin due to the cross-linking by disulfide bonds, hydrogen bonding, and hydrophobic interactions (Ignatova et al., 1999). Plausibly, that resistance to mineralization is the reason why this "waste" nutrient-rich product is not used in production of greenhouse crops as a nutrient source. Because of the high $\mathrm{N}$ content of human hair $(16.5 \% \mathrm{~N}$ in the hair used in this experiment), land filling or surface disposing of hair waste, especially on sandy soils, could result in leaching of nitrates into surface or groundwater. Human hair waste could be composted, as has been demonstrated with sheep wool (Das et al., 1997; Plat et al., 1984; Verville, 1996), another similar keratinaceous product. Composted wool has been used in chickpea and wheat production as a $\mathrm{N}$ source (Tiwari et al., 1989a, 1989b). A major disadvantage of composting of protein-rich feedstocks such as wool, however, is the significant loss of $\mathrm{N}$ (Epstein, 1997). Hence, there are environmental and economic benefits for the use of noncomposted protein-rich materials as $\mathrm{N}$ source for crops over the compost prepared with such materials.

The major impact of hair fertilization on lettuce quality was lower moisture and higher SSC. This result could lead to a "sweeter" flavor in 
lettuce, but the lower moisture may result in decreased crunchiness. These perceptions need to be determined by a sensory panel. Total phenolics did not differ, but there was a perceived trend for hair-treated samples to contain higher phenolics. Color values had slight differences among treatments, but not enough to be discernible by the naked eye. This observation tells us that consumers may not be able to notice the difference among produce grown in these different nutritional regimes. APC of lettuce were average for this product, about $6 \log \mathrm{cfu} / \mathrm{g}$ (Valentin-Bon et al., 2008), and hair treatment did not have any effect. Total coliforms were also below $2 \log \mathrm{cfu} / \mathrm{g}$ (Gilbert et al., 2000; Johnston et al., 2005), indicating good handling practices and the unlikelihood of enteropathogens being present.

Overall, the amount of residual nutrients in growth medium after the harvest of the second crops was above that of the control, indicating a possibility for additional cropping. Furthermore, further mineralization of hair waste would be expected in the hair treatments, which might be able to supply phyto-available nutrients for a subsequent crop, as hair fibers were visible in the growth medium at the time of sampling. However, a potential concern with the use of hair as an amendment and nutrient source for plants is the apparent decrease of growth medium $\mathrm{pH}$ and increase of TSS (Table 3). Similar reduction of soil $\mathrm{pH}$ after the use of hair waste addition has been previously reported (Zheljazkov, 2005). The relatively higher electrical conductivity in the hair treatments might have been the reason for the lower lettuce yields in these treatments relative to the CRF or WSF treatments, as lettuce is known to be a salt-sensitive crop (Kerns et al., 1999).

Further research is needed to match nutrient release from hair waste to crop requirements and to estimate optimal rates of application of hair waste to different containergrown crops. Because human hair may carry biohazards such as human pathogens or chemicals, further research is needed to address possible health concerns of consumers and the general public on the use of human hair waste as nutrient source for edible crops.

\section{Literature cited}

Allende, A., E. Aguayo, and F. Artes. 2004. Microbial and sensory quality of commercial fresh processed red lettuce throughout the production chain and shelf life. Int. J. Food Microbiol. 91(2): 109-117.

American Public Health Association. 1992. Standard methods for the examination of water and wastewater. American Public Health Assn., New York.

Association of Official Analytical Chemists. 1997. Official methods of analysis. 16th ed. Association of Official Analytical Chemists, Washington, DC.

Bernstein, L. 1975. Effects of salinity and sodicity on plant growth. Annu. Rev. Phytopathol. 13:295-312.

Cox, M.S. 2001. The Lancaster soil test method as an alternative to the Mehlich 3 soil test method. Soil Sci. 166:484489.

Das, K., E.W. Tollner, and P.A. Annis. 1997. Bioconversion process design applied to textile industry solid wastes. Amer. Soc. Agr. Eng. Annu. Intl. Mtg., Paper No. 97-5022.

Epstein, E. 1997. Trace elements, heavy metals and micronutrients, p. 137-170. In: The science of composting. E. Epstein (ed.). Technomic Publishing, Lancaster, PA.

Francis, C.W. and C.D. Malone. 1975. Nitrate measurements using a specific ion electrode in presence of nitrite. Soil Sci. Soc. Amer. J. 39:150-151.

Gilbert, R.J., D. Roberts, F.J. Bolton, J. de Louvois, C. Little, T. Donovan, K. Nye, C.D. Ribeiro, and J. Richards. 2000 Guidelines for the microbiological quality of some ready-to-eat foods sampled at the point of sale. Commun. Dis. Public Health 3:163-168.

Ignatova, Z., A. Gousterova, G. Spassov, and P. Nedkov. 1999. Isolation and partial characterization of extracellular keratinase from a wool degrading thermophilic actinomycete strain Thermoactinomyces candidus. Can. J. Microbiol. 45:217-222.

Johnston, L.M., L.A. Jaykus, D. Moll, M.C. Martinez, J. Anciso, B. Mora, and C.L. Moe. 2005. A field study of the microbiological quality of fresh produce. J. Food Prot. 68:18401847.

Jones, J.B., Jr. and W.J.A. Steyn. 1973. Sampling, handling, and analyzing plant tissue samples, p. 249-270. In: L.M. Walsh and J.D. Beaton (eds.). Soil testing and plant analysis. Soil Science Society of America, Madison, WI.
Kerns, D.L., M.E. Matheron, J.C. Palumbo, C.A. Sanchez, D.W. Still, B.R. Tickes, K. Umeda, and M.A. Wilcox. 1999. Guidelines for head lettuce production in Arizona. IPM Ser. No. 12, Publ. No. azl099. 27 Mar. 2008. <http:// ag.arizona.edu/crops/vegetables / cropmgt/azl099.html>.

Kim, T.J., J.L. Silva, R.S. Chamul, and T.C. Chen. 2000. Influence of ozone, hydrogen peroxide, or salt on microbial profile TBARs and color of channel catfish fillets. J. Food Sci. 65:1210-1213.

Plat, J.Y., D. Sayag, and L. Andre. 1984. High-rate composting of wool industry wastes. Biocycle 25:39-42.

Silva, J.L., E. Marroquin, F.B. Matta, J.O. Garner, and J. Stojanovic. 2005. Physicochemical, carbohydrate and sensory characteristics of highbush and rabbiteye blueberry cultivars. J. Sci. Food Agr. 11: 1815-1821.

Singleton, V.L. and J.A. Rossi. 1965. Colorimetry of total phenolics with phosphomolybdic-phosphotungstic acid reagents. Amer. J. Enol. Viticult. 16:144-158.

Stojanovic, J. and J.L. Silva. 2007. Influence of osmotic concentration, continuous high frequency ultrasound and dehydration on antioxidants, color and chemical properties of rabbiteye blueberries. Food Chem. 101:898-906.

Tiwari, V.N., A.N. Pathak, and L.K. Lehri. 1989a. Effect of cattle dung and rock phosphate on composting of woolwaste. Biol. Wastes 27:237-241.

Tiwari, V.N., A.N. Pathak, and L.K. Lehri. 1989b. Response to differently amended wool-waste composts on yield and uptake of nutrients by crops. Biol. Wastes 28:313-318.

Valentin-Bon, I., A. Jacobson, S.R. Monday, and P.C.H. Feng. 2008. Microbiological quality of bagged, cut spinach and lettuce mixes. Appl. Environ. Microbiol. 74(4): 1240-1242.

Verville, R.R. 1996. Organic feedstock generators team up with local farmers. Biocycle 37:58-61.

Willard, H.H., L.L. Merritt, and J.A. Dean. 1968. Instrumental methods of analysis. 4th ed. Van Norstrand, Princeton, NJ.

Zheljazkov, V.D. 2005. Assessment of wool-waste and hair waste as soil amendment and nutrient source. J. Environ. Qual. 34:2310-2317.

Zheljazkov, V.D., G.W. Stratton, and T. Sturz. 2008. Uncomposted wool and hair-wastes as soil amendments for highvalue crops. Agron. J. (In press). 